УДК 621.039(06)

\title{
ОБСЕМЕНЕННОСТЬ КОРЮШКИ (OSMERUS EPERLANUS) БАКТЕРИЯМИ РАЗЛИЧНЫХ ТАКСОНОМИЧЕСКИХ ГРУПП
}

\author{
Е. В. Авдеева, Е. В. Мажуга, О. А. Новожилов \\ SMELT (OSMERUS EPERLANUS) BACTERIA \\ OF VARIOUS TAXONOMIC GROUPS
}

E. V. Avdeeva, E. V. Mazhuga, O. A. Novozhilov

Исследование микрофлоры корюшки проводилось впервые, ранее изучалась только паразитофауна этого вида рыбы. Корюшка - массовый объект питания населения Калининградской области, изучение микрофлоры позволит предотвратить возможные инфекционные заболевания человека. Необходимо осуществлять дальнейший мониторинг по обсемененности бактериями корюшки для своевременного выявления условно-патогенных бактерий, способных вызывать бактериальные заболевания.

Нами были проведены исследования микрофлоры корюшки Osmerus eperlanus (Linneus, 1758) за пятилетний период (2014-2019 гг.).

Материалом послужили 92 экземпляра рыбы из устья р. Неман и р. Матросовки.

Изучали культуральные, морфологические и физиолого-биохимические признаки бактерий по общепринятой в ихтиопатологии методике. Определяли бактерии до рода и вида с помощью Определителя бактерий Берджи по культуральным, морфологическим и физиолого-биохимическим признакам, исследование проводили по 16 тестам.

В микрофлоре корюшки обнаружили 41 вид бактерий, принадлежащих к следующим родам: Acinetobacter, Aeromonas, Alcaligenes, Bacillus, Citrobacter, Enterobacter, Kurthia, Micrococcus, Escherichia, Plesiomonas, Pseudomonas, Renibacterium, Staphylococcus и Streptococcus. Выявили 13 видов условно-патогенных бактерий, которые могут в стрессовых условиях вызвать заболевания исследуемого объекта. Также корюшка была обсеменена тринадцатью видами сапрофитных бактерий, являющихся характерной для нее микрофлорой, и пятнадцатью видами санитарно-значимых бактерий, из них два вида - бактерии группы кишечной палочки, наличие которых свидетельствует о загрязнении воды хозяйственнобытовыми сточными водами в исследуемом нами водоеме.

Микрофлора корюшки из устья р. Неман была не такой разнообразной, как у рыбы из р. Матросовки. Наиболее обсемененные внутренние органы - сердце, печень и селезенка.

Работа актуальна, так как микрофлора корюшки из водоемов Калининградской области исследовалась впервые.

корюшка, p. Матросовка, p. Неман, бактерия, условно-патогенные бактерии, микрофлора, рыба, посев, обсемененность, среды, сапрофитные бактерии 
Smelt is a mass food object of the Kaliningrad region population. The studies of the microflora help to prevent infectious diseases of humans. It is necessary to control bacterization of smelt.

We have studied the microflora of smelt Osmerus eperlanus (Linneus, 1758) over a five-year period (2014-2019).

Totally 92 specimen of smelt from the river Neman and the river Matrosovka have been studied.

Microbiological investigations have been performed by a standard method. We have studied the cultural, morphological and physiological and biochemical characteristics of bacteria. Determination of bacteria has been carried out in 16 tests. Based on the totality of cultural, morphological and physiological and biochemical characteristics, bacteria have been determined to the genus and species using the Bergey Bacteria Detector.

In the results, 41 species of bacteria, which belong to the genus Acinetobacter, Aeromonas, Alcaligenes, Bacillus, Citrobacter, Enterobacter, Kurthia, Micrococcus, Escherichia, Plesiomonas, Pseudomonas, Renibacterium, Staphylococcus and Streptococcus, Escherichia, Plesiomonas, Pseudomonas, Renibacterium, Staphylococcus and Streptococcus have been found in the smelt microflora. 13 species of opportunistic pathogenic bacteria have been identified that can cause diseases of the studied object under stress conditions. Smelt are also bacterized with 13 saprophytic bacteria. They are characteristic microflora for fish. We have found 15 species of sanitary bacteria. They have 2 types of bacteria of the Escherichia coli group. They testify to water pollution by household wastewater in the reservoir under study.

The microflora of smelt from the mouth of the Neman River was not as diverse as the microflora of smelt from the Matrosovka River. The most bacterized organs of smelt are the heart, liver and spleen.

The aim of this work is important, because smelt microflora has been studied for the first time.

smelt, Osmerus eperlanus, river Matrosovka, river Neman, bacteria, pathogenic bacteria, microflora, fish, sowing, contamination, environment, saprophytic bacteria

\section{ВВЕДЕНИЕ}

Корюшка - любимый объект питания населения Калининградской области. В состав мяса этой рыбы входит много витаминов, необходимых человеку, макрои микроэлементов, среди которых особенно важны железо, калий, магний, натрий, фосфор, сера, хлор, фтор и молибден. По содержанию связанного натрия корюшка в числе рекордсменов. Поэтому ее рекомендуется включать в рацион людей с ослабленным здоровьем, а также детей.

Но, к сожалению, корюшка входит в число рыб, к которым врачи и экологи рекомендуют относиться с большой настороженностью, так как велика вероятность наличия в ней различных бактерий и паразитов $[1,2]$.

Исследование микрофлоры корюшки европейской (Osmerus eperlanus eperlanus) проводилось впервые. Ранее кафедрой ихтиологии и экологии изучались нерестовый ход корюшки и ее воспроизводительная способность в реках бассейна Куршского залива [3].

Цель работы - изучение микрофлоры корюшки и выявление условнопатогенных бактерий, которые могут вызвать бактериальные заболевания у данного вида рыб. 


\section{МАТЕРИАЛ И МЕТОДИКА}

Материалом для исследования в 2014-2015 гг. стали 30 экземпляров корюшки из устья р. Неман, в 2016 г. -23 из р. Матросовки, в 2018 г. -20 из устья p. Неман и в 2019 г. - 19 экземпляров из р. Матросовки. Рыба имела размеры от 9,0 до 20,3 см.

Первичный бактериологический посев осуществляли по общепринятой в ихтиопатологии методике [4].

По совокупности культуральных, морфологических и физиологобиохимических признаков определяли бактерии до рода и вида с помощью Определителя бактерий Берджи [5].

\section{РЕЗУЛЬТАТЫ И ОБСУЖДЕНИЯ}

В микрофлоре корюшки обнаружили 41 вид бактерий, в том числе 13 видов сапрофитных (табл. 1).

Таблица 1. Сапрофитные бактерии, обнаруженные в микрофлоре корюшки Table 1. Saprophytic bacteria found in smelt microflora

\begin{tabular}{|c|c|}
\hline Вид бактерии & Локализация в органах \\
\hline Alcaligens faecalis & $\begin{array}{c}\text { Желчный пузырь, жабры, кожа, сердце, } \\
\text { селезенка, почки, желудочно-кишечный } \\
\text { тракт, печень, икра, семенники }\end{array}$ \\
\hline Alcaligenes latus & Жабры, сердце, желчный пузырь \\
\hline Paenibacillus (Bacillus) alvei & Желудочно-кишечный тракт \\
\hline Brevibacillus (Bacillus) brevis & $\begin{array}{c}\text { Кожа, сердце, почки, желудочн- } \\
\text { кишечный тракт, печень }\end{array}$ \\
\hline Bacillus coagulans & Селезенка \\
\hline Bacillus circulans & Почки \\
\hline Bacillus firmus & Кожа, желчный пузырь, печень, почки, \\
желудочно-кишечный тракт
\end{tabular}

Наличие бактерий Alcaligens faecalis указывает на загрязнение воды в заливе хозяйственно-бытовыми сточными водами.

Бациллы, которых обнаружили семь видов, встречаются в воде и грунте и характерны для микрофлоры корюшки, также как и бактерии Kurthia zophii.

При изучении микрофлоры корюшки выявили 15 санитарно-значимых видов бактерий, в частности два вида группы кишечной палочки, присутствие которых свидетельствует о загрязнении исследуемых нами водоемов хозяйственнобытовыми сточными водами в (табл. 2). 
Таблица 2. Санитарно-значимые бактерии в микрофлоре корюшки Table 2. Sanitary bacteria in smelt microflora

\begin{tabular}{|c|c|}
\hline Вид бактерии & Локализация в органах \\
\hline Acinetobacter baumanni & Печень \\
\hline Acinetobacter calcoaceticus & Кожа, жабры, сердце, селезенка, желчный \\
пузырь, печень
\end{tabular}

Наличие бактерий рода Acinetobacter свидетельствует о загрязнении хозяйственно-бытовыми сточными водами, бактерий группы кишечной палочки о свежем фекальном загрязнении Куршского залива.

Микрококки характерны для микрофлоры корюшки.

У корюшки обнаружили 13 видов условно-патогенных бактерий (табл. 3).

Таблица 3. Условно-патогенные бактерии в микрофлоре корюшки

Table 3. Conditionally pathogenic bacteria in smelt microflora

\begin{tabular}{|c|c|}
\hline Вид бактерии & Локализация на органах \\
\hline 1 & 2 \\
\hline Aeromonas caviae & Сердце, селезенка, икра \\
\hline Aeromonas eucrenophila & Сердце \\
\hline Aeromonas veronii & Печень \\
\hline Renibacterium salmoninarum & Жабры \\
\hline Pseudomonas alcaligenes & Сердце \\
\hline Burkholderia & Желчный пузырь, кожа, жабры, сердце, \\
(Pseudomonas) cepacia & желчный пузырь, печень \\
\hline Brevundimonas (Pseudomonas) & Сердце, селезенка, икра \\
\hline diminuta &
\end{tabular}


Научный журнал «Известия КГТУ», № 57, 2020 г.

\begin{tabular}{|c|c|}
\hline \multicolumn{2}{|c|}{ Окончание табл. 3} \\
\hline 1 & 2 \\
\hline Pseudomonas putida & Сердце, селезенка \\
\hline $\begin{array}{c}\text { Shewanella } \\
\text { (Pseudomonas) putrefaciens }\end{array}$ & Печень, семенники \\
\hline Pseudomonas stutzeri & Селезенка \\
\hline Streptococcus bovis & Почки, жабры, печень, икра, семенники \\
\hline Streptococcus canis & Печень, желудочно-кишечный тракт \\
\hline Peptostreptococcus & Кожа, почки \\
\hline (Streptococcus) parvulus & Коч \\
\hline
\end{tabular}

Бактерии Renibacterium salmoninarum вызывают бактериальную почечную болезнь у лососевых, также они встречаются у многих видов морских и пресноводных рыб. Локализуются обычно в паренхиматозных органах, нами эти бактерии были обнаружены на жабрах. Как известно, жабры и кожа рыб являются путями проникновения бактериальных инфекций.

Aeromonas caviae, Aeromonas eucrenophila, Aeromonas veronii, Burkholderia (Pseudomonas) cepacia, Brevundimonas (Pseudomonas) diminuta, Pseudomonas putida, Pseudomonas alcaligenes, Pseudomonas stutzeri, Shewanella (Pseudomonas) putrefaciens являются условно-патогенными бактериями для рыб и могут вызвать у них различные септические процессы.

Бактерии рода Aeromonas являются возбудителями аэромоноза. Он встречается во всех водоемах, заболеванию подвергаются все виды морских рыб.

В микрофлоре корюшки было обнаружено шесть видов псевдомонад, которые могут вызывать псевдомоноз. Это общее название заболевания тепловодных, холодноводных и аквариумных рыб, возбудителями которого являются микроорганизмы - обитатели почвы, пресной и морской воды.

К псевдомонадам чувствительны почти все виды пресноводных и морских рыб. Болезнь появляется при понижении температуры воды в осенне-летний период, но чаще всего во второй половине зимовки (с января по март) и протекает одновременно с массовой гибелью заболевших рыб.

Также изучали обсемененность кожи, жабр и внутренних органов корюшки.

На протяжении всего периода исследования нами была обнаружена обсемененность:

кожи - тремя видами сапрофитных, пятью видами санитарно-значимых и двумя видами условно-патогенных бактерий;

жабр - пятью видами сапрофитных, четырьмя видами санитарно-значимых и тремя видами условно-патогенных бактерий;

сердца - четырьмя видами сапрофитных, шестью видами санитарнозначимых и четырьмя видами условно-патогенных бактерий;

селезенки - тремя видами сапрофитных, восемью видами санитарнозначимых и тремя видами условно-патогенных бактерий;

печени - четырьмя видами сапрофитных, шестью видами санитарнозначимых и пятью видами условно-патогенных бактерий;

почек - шестью видами сапрофитных, четырьмя видами санитарнозначимых и двумя видами условно-патогенных бактерий;

желудочно-кишечного тракта - шестью видами сапрофитных, семью видами санитарно-значимых и одним видом условно-патогенных бактерий; 
желчного пузыря - тремя видами сапрофитных, семью видами санитарнозначимых и двумя видами условно-патогенных бактерий;

семенников - двумя видами сапрофитных и двумя видами условнопатогенных бактерий;

икры - двумя видами сапрофитных и двумя видами условно-патогенных бактерий.

Среди условно-патогенных бактерий были обнаружены Renibacterium salmoninarum, вызывающие бактериальную почечную болезнь у лососевых. Они выявлены у многих видов морских и пресноводных рыб, локализуются, как правило, в паренхиматозных органах. Нами эти бактерии были обнаружены на жабрах. Как известно, жабры и кожа рыб являются путями проникновения бактериальных инфекций.

Таким образом, наиболее обсемененными были сердце, печень и селезенка. Микрофлора корюшки из р. Матросовки более разнообразна по сравнению с микрофлорой рыбы из устья р. Неман. Самая высокая обсемененность бактериями отмечена у корюшки в 2016 г.

\section{ЗАКЛЮЧЕНИЕ}

Сапрофитные бактерии характерны для микробиоценоза корюшки.

Наличие санитарно-значимых бактерий свидетельствует о загрязнении водоема хозяйственно-бытовыми сточными водами. В микрофлоре корюшки было обнаружено большее количество именно таких бактерий, следовательно, идет увеличение антропогенного воздействия на залив, что приводит к его эвтрофикации.

Корюшка была обсеменена тринадцатью видами условно-патогенных бактерий, патогенность которых определяли по наличию протеолитических ферментов [6], все выявленные условно-патогенные бактерии обладали такими ферментами.

Условно-патогенные бактерии, обсеменяющие корюшку, не представляют для нее опасности в естественных условиях обитания. Необходимо осуществлять дальнейший мониторинг по бактериальной обсемененности корюшки и снетка для своевременного выявления условно-патогенных бактерий, способных вызывать у них эпизоотии.

\section{СПИСОК ИСПОЛЬЗОВАННЫХ ЛИТЕРАТУРНЫХ ИСТОЧНИКОВ}

1. Евдокимова, Е. Б. Фауна паразитов корюшки и снетка Куршского залива в устье реки Неман / Е. Б. Евдокимова, Е. В. Авдеева, С. К. Заостровцева // Известия Калининградского государственного технического университета. - 2018.№ 50. - С. 74-80.

2. Гаевская, А. В. Справочник основных болезней и паразитов промысловых рыб Атлантического океана / А. В. Гаевская, А. А Ковалева. - Калининград: Кн. изд-во, 1991. - 208 с.

3. Шибаев, С. В. Нерестовый ход корюшки (Osmerus eperlanus eparlanus L.) в реках бассейна Куршского залива / С. В. Шибаев, А. В. Соколов, К. В. Тылик // Вестник Балтийского федерального университета им. И. Канта. - 2012.- № 7. C. 91-96. 
4. Общая и санитарная микробиология с техникой микробиологических исследований / под ред. А. С. Лабинской, Л. П. Блинковой, А. С. Ещиной. Москва: Медицина, 2004. - 576 с.

5. Определитель бактерий Берджи: в 2 т.: пер. с англ. / под ред. Дж. Хоулта, Н. Крига, П. Снита, Дж. Стейли, С. Уилльямса. - Москва: Мир, 1997. - 780 с.

6. Авдеева, Е. В. Методы диагностики болезней рыб: учеб. пособие / Е. В Авдеева, О. В. Казимирченко, М. Ю. Котлярчук. - Калининград: Изд-во ФГБОУ ВО "КГТУ", 2010. - 101 с.

\section{REFERENCES}

1. Evdokimova E. B., Avdeeva E. V., Zaostrovtseva S. K. Fauna parazitov koryushki $i$ snetka Kurshskogo zaliva $v$ ust'e reki Neman [Fauna of smelt parasites and smelt of the Curonian lagoon at the mouth of the Neman River]. Izvestiya KGTU, 2018, no. 50 , pp. $74-80$.

2. Gaevskaya A. V., Kovaleva A. A. Spravochnik osnovnykh bolezney i parazitov promyslovykh ryb Atlanticheskogo okeana [Reference book of the main diseases and parasites of commercial fish in the Atlantic Ocean]. Kaliningrad, Kn. izd-vo, 1991, 208 p.

3. Shibaev S. V., Sokolov A. V., Tylik K. V. Nerestovyy khod koryushki (Osmerus eperlanus eparlanus L.) v rekakh basseyna Kurshskogo zaliva [Spawning run of smelt (Osmerus eperlanus eparlanus L.) in the rivers of the Curonian lagoon basin]. Vestnik BFU im. Kanta, 2012, no. 7, pp. 91-96.

4. Obshchaya i sanitarnaya mikrobiologiya s tekhnikoy mikrobiologicheskikh issledovaniy [General and sanitary microbiology with the technique of microbiological research]. Moscow, Meditsina, 2004, 576 p.

5. Holt J., Krieg N., Sneath P., Staley J., Williams S. Bergey`s Manual of Determinative Bacteriology. USA, Williams \& Wilkins, 1994. 780 p. ( Russ. Ed. Holt J., Krieg N., Sneath P., Staley J., Williams S. Opredelitel' bakteriy Berdzhi. Moscow, Mir, 1997, 780 p.)

6. Avdeeva E. V., Kazimirchenko O. V., Kotlyarchuk M. Yu. Metody diagnostiki bolezney ryb: uchebnoe posobie [Methods of diagnosis of fish diseases: textbook]. Kaliningrad, FGBOU VO "KGTU", 2010, 101 p.

\section{ИНФОРМАЦИЯ ОБ АВТОРАХ}

Авдеева Елена Витальевна - Калининградский государственный технический университет; кандидат биологических наук, профессор кафедры ихтиопатологии и гидробиологии; E-mail: elavd@ @ail.ru

Avdeeva Elena Vitalievna - Kaliningrad State Technical University; $\mathrm{PhD}$ in Biological Sciences, Professor of the Department of Ichthyopathology and Hydrobiology;

E-mail: elavd@mail.ru

Мажуга Елизавета Владимировна - Калининградский государственный технический университет; магистр водных биоресурсов и аквакультуры;

E-mail: mazhuga.eliz@yandex.ru 
Mazhuga Elizaveta Vladimirovna - Kaliningrad State Technical University; holder of a master degree in Aquatic Bioresources and Aquaculture;

E-mail: mazhuga.eliz@yandex.ru

Новожилов Олег Анатольевич - Калининградский государственный технический университет; кандидат биологических наук; доцент кафедры ихтиологии и экологии; E-mail: ecology@klgtu.ru

Novozhilov Oleg Anatolievich - Kaliningrad State Technical University; $\mathrm{PhD}$ in Biological Sciences; Associate Professor of the Department of Ichthyology and Ecology; E-mail: ecology@klgtu.ru 